\title{
Plant Hosts of Xylella fastidiosa In and Near Southern California Vineyards
}

\author{
H. S. Costa, E. Raetz, and T. R. Pinckard, Department of Entomology, University of California, Riverside 92521; \\ C. Gispert, University of California Cooperative Extension, Indio 92201; and R. Hernandez-Martinez, \\ C. K. Dumenyo, and D. A. Cooksey, Department of Plant Pathology, University of California, Riverside 92521
}

\begin{abstract}
Costa, H. S., Raetz, E., Pinckard, T. R., Gispert, C., Hernandez-Martinez, R., Dumenyo, C. K., and Cooksey, D. A. 2004. Plant hosts of Xylella fastidiosa in and near southern California vineyards. Plant Dis. 88:1255-1261.

Xylella fastidiosa is a xylem-limited bacterium that causes Pierce's disease (PD) of grapevines. A variety of plant species found near a severe outbreak of PD in vineyards in the Temecula Valley of California were tested using enzyme-linked immunosorbent assay, culture on media, and polymerase chain reaction to identify potential inoculum sources in the area. Species that consistently tested positive for X. fastidiosa were the known hosts, grape, almond, and oleander, and two new hosts, Spanish broom (Spartium junceum) and wild mustard (Brassica spp). Sequence analysis of the 16S-23S rRNA spacer region found that strains isolated from grapevine, Spanish broom, wild mustard, and almond clustered with previously sequenced PD strains. Thus, these species could serve as sources of inoculum for infection of grapevines and should be removed or monitored for signs of infection. Sequences from oleander isolates from Temecula formed another cluster with a previously published oleander strain sequence. Oleander strains do not infect grapevines and thus do not appear to cause a direct threat to grapevines. Two additional isolates from almond were determined to be genetically different from PD strains, and the ability of these strains to infect grapevine is not known. Greenhouse transmission studies indicate that the glassy-winged sharpshooter was able to transmit a PD strain of $X$. fastidiosa to Spanish broom, black mustard, and other hosts.
\end{abstract}

Xylella fastidiosa Wells is a xylem-limited bacterium that can cause a number of plant diseases in a wide range of plant hosts in North and South America, including Pierce's disease (PD) of grapevines, almond leaf scorch (ALS), alfalfa dwarf, citrus variegated chlorosis, leaf scorch of live oak, pear leaf scorch, and oleander leaf scorch (OLS) $(5,10,16,18)$. Diseases caused by this pathogen threaten some of California's largest agricultural commodities, including the grape and wine industries, almond, alfalfa, and ornamental nursery production (10). Thus far, strains of $X$. fastidiosa that cause PD of grapevines, ALS, OLS, and alfalfa dwarf have been identified in California, and the PD and OLS strains have caused devastating losses of grapevines and oleander plants, respectively. Strains of the pathogen that cause PD and OLS form two genetically distinct groups (6), and the strains that infect oleander do not infect grape, and vice versa

Corresponding author: H. S. Costa

E-mail: heather.costa@ucr.edu

This project was funded in part by the American Vineyard Foundation and the California Department of Food and Agriculture-Pierce's Disease and Glassy-winged Sharpshooter Board.

Accepted for publication 30 June 2004.

Publication no. D-2004-0830-03R

(C) 2004 The American Phytopathological Society
(18). The PD strains appear to have a broader host range than OLS strains; however, the complete host range of each group is not yet known (10).

In southern California, the primary insect vector of $X$. fastidiosa is the glassywinged sharpshooter (GWSS), Homalodisca coagulata (Say), a recent introduction from the southeastern United States $(3,23)$. This insect feeds on xylem tissue, and is reported to feed on over 75 species of plants in 35 families (26). The habits and host range of GWSS differ from those of other leafhopper vectors in California that previously have been associated with this pathogen. Studies in northern California suggest that the PD pathogen is primarily spread by leafhopper vectors that move into vineyards from outside habitats $(15,17)$. Thus, studies of alternative plant hosts and inoculum sources of $X$. fastidiosa conducted in northern California concentrated on plants in riparian habitats surrounding vineyards. However, in grapegrowing regions of southern California, the habitats and plant hosts that surround vineyards are much different from those found in northern California. In addition to naturally occurring vegetation, vineyards in southern California frequently are adjacent to citrus groves and suburban landscapes.

Knowledge of the source of disease inoculum is essential to the development of effective disease management strategies. Because $X$. fastidiosa has a broad host range and, in some cases, can be present in plant tissue without causing noticeable symptoms (17), it is not always easy to identify plants that serve as alternate hosts and potential sources of inoculum. The objective of this study was to determine which plant species in southern California are hosts of $X$. fastidiosa and serve as potential sources of inoculum for PD infection of grapevine. Because more than one strain of $X$. fastidiosa could be present in our sampling area, it was necessary to further characterize the strains isolated to determine if they were PD strains that would be considered a threat to grapevines in the area. For example, although plant species harboring PD strains could serve as a source of inoculum to infect grapevines, those species harboring OLS strains of $X$. fastidiosa would not be a threat to vineyards, because those strains do not infect grapevines. This type of information can be used to develop management strategies to reduce the spread of disease by removing potential alternate hosts of the pathogen as necessary.

\section{MATERIALS AND METHODS}

Native, introduced, and cultivated plants growing in or near infected vineyards were surveyed at 10 locations throughout the Temecula Valley, CA and surrounding areas for $21 / 2$ years. Because titers of the bacterium in infected plants can vary with season (20), plants were sampled repeatedly at different times of the year to assure detection. Collections were made twice monthly during peak detection season (May to October), and every 1 to 2 months when incidence of detection dropped off (November to April). Sampling locations included vineyards adjacent to commercial citrus groves; landscape plantings, including almond and oleander plants; and various native chaparral and riparian plant communities. In some cases, individual plants were labeled and repeatedly sampled over time. Samples were analyzed for the presence of $X$. fastidiosa using commercial enzyme-linked immunosorbent assay (ELISA) test kits, culture on specialized media, or polymerase chain reaction (PCR) analysis as described below.

ELISA. The PathoScreen Kit (Agdia Inc., Elkhart, IN) was used for ELISA according to the manufacturer's recommendations. Essentially, a 2- to $3-\mathrm{cm}$ length section of leaf petioles and midvein were cut from leaves and sliced crosswise into fine sections about 2 to $3 \mathrm{~mm}$ thick in 
$100 \mu \mathrm{l}$ of general extraction buffer using flame-sterilized razor blades and forceps. The sliced plant tissue and buffer slurry was scraped into a $1.5-\mathrm{ml}$ microcentrifuge tube containing $1 \mathrm{ml}$ of ELISA extraction buffer (supplied in the kit) on ice. Alternatively, plant samples were macerated in 1 $\mathrm{ml}$ of extraction buffer in plastic sample bags (Agdia Inc.). Samples were loaded into 96-well microtiter plates and processed. The results of the analysis were read on a Benchmark microtiter plate reader (BioRad, Hercules, CA) at a wavelength of $490 \mathrm{~nm}$. Samples were considered positive if the absorbance was greater than two times the negative control.

Culture on media. Media used were PD3 (4) and PW (29) in 6-cm-diameter sterile petri dishes. Samples for culturing were prepared as follows: sections of leaf petioles and midvein, 2 to $3 \mathrm{~cm}$ in length, were cut from leaves, surface sterilized by soaking for $2 \mathrm{~min}$ in $95 \%$ ethanol and 2 min in $20 \%$ bleach (1:5 dilution of a $5.25 \%$ bleach solution), then rinsed twice for $2 \mathrm{~min}$ in distilled water. The clean plant tissue was sliced crosswise into fine sections about 2 to $3 \mathrm{~mm}$ wide in $100 \mu \mathrm{l}$ of sterile phosphate-buffered saline (PBS) buffer (29) using flame-sterilized razor blades and forceps. The tissue was soaked in buffer at room temperature for $10 \mathrm{~min}$, $45 \mu \mathrm{l}$ of liquid was transferred to each type of specialized media plate using a micropipette, and the liquid was distributed over the surface by tilting the plate. Plates were incubated at $28^{\circ} \mathrm{C}$ and evaluated at 1,2 , and 6 weeks after extraction.

DNA extraction. Commercially available DNA extractions kits (Qiagen DNeasy
Plant Mini Kit, \#69104; Qiagen Inc., Valencia, CA) were used to extract DNA from plant tissue. All samples were extracted in disposable, mesh-lined sample bags (Agdia Inc.) that allowed straining before processing to remove large particles of plant material. A 2- to $3-\mathrm{cm}$ length of plant petiole, leaf vein, or thin branch tissue from symptomatic branches was placed in the sample bag with $300 \mu$ of PBS buffer. Additional buffer was added if needed to allow collection of $180 \mu \mathrm{l}$ of strained liquid for processing. Samples were homogenized using a ceramic pestle on the outside of bags resting on a hard surface. Strained liquid ( $180 \mu \mathrm{l})$ was transferred from the bag to a $1.5-\mathrm{ml}$ microcentrifuge tube, and the samples were processed according to instructions of the kit manufacturer.

PCR amplification. For consistency and ease of amplification, Ready-to-go PCR beads (Amersham Pharmacia Biotech Inc, Piscataway, NJ) were used for PCR (final concentration: $10 \mathrm{mM}$ Tris- $\mathrm{HCl}, 50$ $\mathrm{mM} \mathrm{KCl}, 1.5 \mathrm{mM} \mathrm{MgCl}$, dNTP mix at $200 \mu \mathrm{M}$ each, and $3 \mathrm{U}$ of Taq DNA polymerase). Amplification was performed using the RST31/RST33 primer pair (12) for general amplification of $X$. fastidiosa. Each reaction contained one Ready-to-go PCR bead, $0.25 \mu \mathrm{l}$ of each of primer $(25$ $\mathrm{pM} / \mu \mathrm{l}$ of solution), and $5 \mu \mathrm{l}$ of DNA extract, with sterile water added to make 25 $\mu \mathrm{l}$ of total volume. Amplification was done in a thermal cycler (GeneAmp PCR System 9700; PE Applied Biosystems, Foster City, CA) programmed for $95^{\circ} \mathrm{C}$ for $5 \mathrm{~min}$; followed by 35 cycles of $94^{\circ} \mathrm{C} 40 \mathrm{~s}, 55^{\circ} \mathrm{C}$ $40 \mathrm{~s}, 72^{\circ} \mathrm{C} 1 \mathrm{~min}$, and a final $72^{\circ} \mathrm{C}$ for 5

Table 1. Host plant sources and GenBank accession numbers for 16S-23S rDNA intergenic spacer sequences of the Xylella fastidiosa isolates used in this study

\begin{tabular}{llll}
\hline Strain designation & Host & GenBank accession no. & \multicolumn{1}{c}{ Reference } \\
\hline 237 & Almond & AY603086 & This study \\
239 & Almond & AY603082 & This study \\
189 & Almond & AY603083 & This study \\
H50 & Almond & AY604730 & This study \\
H51 & Almond & AY603080 & This study \\
276 & Almond & AY603084 & This study \\
Dixon & Almond & AF073251 & Hendson et al. 2001 \\
ALS2 & Almond & AF073243 & Hendson et al. 2001 \\
Tulare & Almond & AF073242 & Hendson et al. 2001 \\
H10 & Almond & AY603085 & This study \\
SAAP110 & White sage & AY603094 & This study \\
SAAP102 & White sage & AY603092 & This study \\
SAME109 & Black sage & AY603093 & This study \\
G10 & Brassica sp. & AY603091 & This study \\
N10 & Spanish broom & AY603081 & This study \\
Temecula & Grape & NC_004556 & Van Sluys et al. 2003 \\
I03 & Grape & AY603089 & This study \\
A05 & Grape & AY603090 & This study \\
STL & Grape & AF073228 & Hendson et al. 2001 \\
H44 & Oleander & AY603088 & This study \\
H45 & Oleander & AY603087 & This study \\
Ann1 & Oleander & AF073215 & Purcell et al. 1999 \\
CI.52 & Citrus & AF203389 & Y. Rosato et al. 1998 \\
CO.01 & Coffee & AF203390 & Y. Rosato et al. 1998 \\
PE.PLS & Pear & AF203392 & Y. Rosato et al. 1998 \\
\hline
\end{tabular}

a These hosts were inoculated with $X$. fastidiosa from infected grapevines using the glassy-winged sharpshooter vector in laboratory studies. min; then held at $4^{\circ} \mathrm{C}$. Products were run on $2 \%$ agarose gels and stained using ethidium bromide $(0.5 \mu \mathrm{g} / \mathrm{ml}$ of gel $)$ to visualize product.

Characterization of pathogen strains by analysis of the $16 \mathrm{~S}-23 \mathrm{~S}$ intergenic spacer region. The $16 \mathrm{~S}-23 \mathrm{~S}$ rRNA intergenic spacer regions of $X$. fastidiosa strains were PCR amplified using primers G1 (5'GAAGTCGTAACAAGG-3') and L1 (5'CAAGGCATCCACCGT-3') as described previously by Hendson et al. (6). After the amplified products were purified using Ultrafree tubes (Millipore, Billerica, MA), each fragment was sequenced in both directions and the ends were eliminated according to other $X$. fastidiosa strains sequences obtained from GenBank. The nucleotide sequence accession numbers of the amplified DNA as well as some other sequences obtained from GenBank are given in Table 1. All the 16S-23S rRNA sequences were aligned using the ClustalX program (25) and their relationship was resolved using the PAUP software program, with the sequence of the pear strain of X. fastidiosa (AF203392) as an outlying group (24). The reproducibility of the resulting tree was assessed by performing 100 bootstraps.

Immunocapture/PCR methods. Immunocapture/PCR (IC/PCR) methods were modified from protocols provided by California Seed and Plant Lab, Inc. (Elverta, CA) and Pooler et al. (14). Antibody-coated magnetic immunocapture beads were made by mixing $244 \mu \mathrm{l}$ of coating antibody anti- $X$. fastidiosa (Agdia Inc.) with $500 \mu \mathrm{l}$ of sheep anti-rabbit immunoglobulin-G-coated magnetic beads (Dynabeads M-280; Dynal Biotech, Lake Success, NY) and incubating at $4^{\circ} \mathrm{C}$ for $24 \mathrm{~h}$. Approximately $3 \mathrm{~cm}$ of stem, leaf petiole, or petiole plus midvein was ground in a mesh sample bag (Agdia Inc.) with $1 \mathrm{ml}$ of succinate-citrate-phosphate (SCP) buffer, $\mathrm{pH}$ 7. The strained liquid extract was transferred to a $1.5-\mathrm{ml}$ tube and centrifuged at $14,000 \mathrm{rpm}$ for $15 \mathrm{~min}$. The supernatant was discarded, and the pellet was resuspended in $500 \mu \mathrm{l}$ of $0.2 \%$ bovine serum albumin (BSA) in a PBS buffer $(\mathrm{pH}$ 7.4), and $10 \mu \mathrm{l}$ of coated immunocapture magnetic beads were added. Samples were incubated for $2 \mathrm{~h}$ at $4^{\circ} \mathrm{C}$ with gentle shaking. Beads were restrained against the wall of the microcentrifuge tube with a magnet (model MPC-S Dynal Biotech), washed three times with PBS/BSA buffer, released from the magnet, and resuspended in $10 \mu \mathrm{l}$ of water.

Comparison of ELISA and IC/PCR techniques for early-season detection. An IC/PCR method was tested and compared to standard ELISA to determine if it could more effectively detect infected grapevines early in the growing season. Samples were collected two times, once in May and once in June, from grapevines in Temecula, CA. Leaf samples were collected from 25 grapevines that showed 
symptoms of infection in the previous year, 10 vines that were nonsymptomatic, and 10 negative control vines that were maintained in the greenhouse and not exposed to $X$. fastidiosa. In addition, samples were collected from three infected and two uninfected oleander plants maintained in a greenhouse. The infected oleander plants were known to have titers high enough to test positive with ELISA, and were used as positive controls. Each sample was divided into two subsamples that were tested with either ELISA or IC/ PCR (as described above), and analyzed to determine the relative number of plants that tested positive at each time using each method.

Transmission experiments. Greenhouse experiments were conducted to determine which plant species could become infected with an $X$. fastidiosa PD strain from grapevine when transmitted by $H$. coagulata. Thirty plant species were selected for greenhouse testing in transmission experiments (Table 2). Criteria for selection included one or more of the following: (i) species commonly found in the Temecula Valley near outbreaks of PD, (ii) species previously reported as hosts of $X$. fastidiosa, (iii) species that occasionally tested weakly positive by ELISA in our field collections, or (iv) species that were preferred hosts of $H$. coagulata.

PD-infected grapevine source plants were confirmed with ELISA or PCR as described above. Transmission test plants were screened with ELISA and found to be uninfected before use. Field-collected $H$. coagulata adults were caged on branches of known PD-infected grapevines for at least $24 \mathrm{~h}$ to ensure adequate opportunity for acquisition of the pathogen (1). Insects then were collected from infected plants and placed on uninfected test plants (three to five insects per plant) and allowed to feed for at least 3 days. Plant species were inoculated in groups of 10 , with each spe- cies replicated three times. In each transmission experiment, grapevines were included as positive controls to demonstrate that $X$. fastidiosa was present in source plants at high enough levels to allow transmission from that source. Inoculated test plants were maintained in a greenhouse and tested for the presence of $X$. fastidiosa at 3, 6, 9, and 12 months after inoculation using ELISA. Positive samples were confirmed using PCR as described above. The number of plants testing posi-

Table 3. Plant species collected from Temecula, CA that tested positive for the presence of Xylella fastidiosa using commercial enzyme-linked immunosorbent assay (ELISA) kits, culturing on specialized media, or polymerase chain reaction (PCR)

\begin{tabular}{llcccc}
\hline Common name & \multicolumn{1}{c}{ Scientific name } & Total tested & ELISA & PCR & Culture \\
\hline Almond & Prunus spp. & 155 & + & + & + \\
Grape & Vitis vinifera & 970 & + & + & + \\
Wild mustard & Brassica spp. & 380 & + & + & + \\
Oleander & Nerium oleander & 137 & + & + & + +a \\
Spanish broom & Spartium junceum & 147 & + & + & + \\
Citrus & Citrus spp. & 375 & + & - & - \\
Coyote brush & Baccharis pilularis & 65 & + & - & - \\
Elderberry & Sambucus spp. & 161 & + & - & - \\
Ivy & Hedera helix & 25 & + & - & - \\
Olive & Olea europaea & 125 & + & - & - \\
Pepper tree & Schinus molle & 100 & + & - & - \\
Pistachio & Pistachia vera & 40 & + & - & - \\
Silverleaf nightshade & Solanum elaeagnifolium & 40 & + & - & - \\
Toyon & Heteromeles arbutifolia & 60 & + & - & - \\
Walnut & Juglans californica & 46 & + & - & - \\
Willow & Salix spp. & 151 & + & - & - \\
\hline
\end{tabular}

${ }^{a}$ Identified as the oleander leaf scorch strain, which is not known to infect grape.

Table 2. Plant species tested in greenhouse studies using the glassy-winged sharpshooter to transmit Xylella fastidiosa from infected grape plants ${ }^{\mathrm{a}}$

\begin{tabular}{|c|c|c|c|c|c|}
\hline \multirow[b]{2}{*}{ Plant name } & \multirow[b]{2}{*}{ Common name } & \multirow[b]{2}{*}{ Total no. of test plants } & \multicolumn{3}{|c|}{ No. positive } \\
\hline & & & ELISA & PCR & Culture \\
\hline Brassica nigra & Black mustard & 48 & 20 & + & + \\
\hline Salvia apiana & White sage & 10 & 3 & + & + \\
\hline Salvia mellifera & Black sage & 20 & 19 & + & + \\
\hline Spartium junceum & Spanish broom & 30 & 14 & + & + \\
\hline Prunus dulcis & Almond (Butte) & 28 & 4 & + & + \\
\hline Sambucus mexicana & Mexican elderberry & 9 & 4 & + & + \\
\hline Coprosma repens & Mirror plant & 30 & 17 & + & $\ldots$ \\
\hline Medicago sativa & Alfalfa & 30 & 1 & + & $\ldots$ \\
\hline Artemisia californica & California sagebrush & 10 & 0 & - & nt \\
\hline Artemisia douglasiana & Mugwort & 30 & 0 & - & nt \\
\hline Baccharis pilularis & Coyote brush & 28 & 1 & - & - \\
\hline Baccharis salicifolia & Mule fat & 30 & 0 & - & $\mathrm{nt}$ \\
\hline Bougainvillea spp. & Bougainvillea & 30 & 0 & - & nt \\
\hline Citrus limon & Lemon (Frost Eureka) & 30 & 1 & - & nt \\
\hline Citrus $\times$ paradisi & Grapefruit (Duncan) & 30 & 0 & - & - \\
\hline Citrus sinensis & Sweet orange & 30 & 0 & - & nt \\
\hline Cynodon dactylon & Bermudagrass & 30 & 0 & - & nt \\
\hline Encelia farinosa & Brittlebush & 15 & 1 & - & - \\
\hline Eriogonum fasciculatum & Buckwheat & 30 & 0 & - & nt \\
\hline Heteromeles arbutifolia & Toyon & 20 & 0 & - & nt \\
\hline Lagerstroemia indica & Crape myrtle & 30 & 0 & - & nt \\
\hline Malosma laurina & Laurel sumac & 8 & 0 & - & nt \\
\hline Nerium oleander & Oleander & 30 & 1 & - & - \\
\hline Platunus racemosa & Sycamore (California) & 20 & 3 & - & nt \\
\hline Prunus persica & Peach (O’Henry) & 30 & 0 & - & nt \\
\hline Prunus sp. & Peach (Nemagard rootstock) & 30 & 1 & - & nt \\
\hline Prunus americana & Plum (native) & 20 & 1 & - & - \\
\hline Quercus agrifolia & Coast live oak & 30 & 2 & - & nt \\
\hline Rhus ovata & Sugar bush & 30 & 0 & - & nt \\
\hline Sambucus americana & American elderberry & 5 & 0 & - & nt \\
\hline
\end{tabular}

${ }^{a}$ Plants were tested for the presence of $X$. fastidiosa using commercial enzyme-linked immunosorbent assay (ELISA) kits, media culturing methods, and strain-specific primers for polymerase chain reaction (PCR) analysis; $\ldots=$ unable to isolate from infected plants: all cultures were contaminated and $\mathrm{nt}=$ not tested. 
tive within 1 year was recorded. When possible, new species testing positive in transmission studies were cultured, and isolates extracted and sequenced as described above to demonstrate that they were a PD strain.

\section{RESULTS}

Field samples. Over 60 species of plants and more than 5,000 samples were processed for the field surveys. Of the species tested in the Temecula Valley, only grape (Vitis vinifera), almond (Prunus sp.), Spanish broom (Spartium junceum), wild mustard (Brassica spp.) and oleander (Nerium oleander) consistently tested positive for X. fastidiosa with all methods (Table 3). To our knowledge, this report is the first to identify wild mustard and Spanish broom as hosts of $X$. fastidiosa. In the field, many Brassica spp. plants tested positive with both ELISA and PCR, but we were able to obtain only a single isolate of $X$. fastidiosa from field samples of Brassica spp. for unknown reasons. Field samples of citrus, coyote brush, elderberry, and a few other species occasionally tested positive with ELISA (Table 3); however, we were not able to confirm those results with PCR or culture.

The ability to detect the pathogen in leaf and petiole tissue of these hosts varied through the season. We were unable to detect the pathogen of grapevine and almond using ELISA in early spring (Table 4); however, some samples of Spanish broom and oleander tested positive all year. Wild mustard plants tested positive in midsummer, and generally were not present in the field during the winter months.

Plant species sampled from the field that did not test positive by any method were avocado, Persea spp., $n=40$ samples tested; bermudagrass, Cynodon dactylon, $n$ = 25; bottletree, Brachychiton populneus, $n$ = 15; bougainvillea, Bougainvillea spp., $n$ = 30; brittlebush, Encelia spp., $n=30$; buffalo gourd, Cucurbita foetidissim, $n=$ 25; cheeseweed, Malva parviflora, $n=$ 159; cherry, Prunus spp., $n=5$; Clover, Melilotus spp., $n=15$; coastal live oak, Quercus agrifolia, $n=35$; common nightshade, Solanum americanum, $n=30$; crape myrtle, Lagerstroemia indica, $n=23$; daisy, Erigeron spp. $n=20$; datura, Datura meteloides, $n=31$; dodder, Cuscuta spp., $n$ =13; eucalyptus, Eucalyptus spp., $n=121$; fiddleneck, Amsinkia intermedia, $n=30$; filaree, Erodium spp., $n=15$; gingko biloba, Gingko spp., $n=5$; laurel sumac, Rhus laurina, $n=32$; loquat, Eriobotrya japonica, $n=6$; mugwort, Artemisia spp., $n=25$; mulberry, Morus papyrifera, $n=$ 55; mulefat, Baccharis salicifolia, $n=20$; ornamental plum, Prunus cerasifera, $n=$ 45; peach or nectarine, Prunus persica, $n=$ 30; periwinkle, Vinca spp., $n=35$; plum, Prunus domestica, $n=16$; pomegranate, Punica granatum, $n=38$; poplar, Populus spp., $n=90$; redroot pigweed, Amaranthus retroflexus, $n=55$; ripgut brome, Bromus rigidus, $n=30$; rose, Rosa spp., $n=9$; sage, Salvia spp., $n=20$; scarlet pimpernel, Anagallis arvensis, $n=20$; sowthistle, Sonchus oleraceus, $n=25$; sugarbush, Rhus ovata, $n=25$; sunflower, Helianthus annuus, $n=15$; sweet gum, Liquidambar spp., $n=47$; sycamore, Platanus spp., $n=$ 59; telegraphplant, Heterotheca grandiflora, $n=15$; tree tobacco, Nicotiana glauca, $n=$ 47; umbrella sedge, Cyperus eragrostis, $n=$ 15; velvet turtleneck, Psathyrotes ramosissima, $n=10$; wild barley, Hordeum leporinum, $n=30$; wild buckwheat, Eriogonum spp., $n=85$; and yerba santa, Eriodictyon crassifolium, $n=25$.

Comparison of ELISA and IC/PCR for early season detection. In the first collection of grapevines sampled in spring (May), 15 of 25 samples from symptomatic field grape plants and 0 of 10 of the nonsymptomatic plants tested positive by ELISA (Table 5). IC/PCR of the same samples did not detect any infected grapevines at that time. Both methods did detect $X$. fastidiosa in the infected oleander plants used as positive controls. In samples collected 5 weeks later (June), 8 of 21 symptomatic grapevines were positive for the bacterium with ELISA, and 7 of these same samples also tested positive with IC/PCR. In this case, analysis of samples with IC/PCR early in the season did not help to detect any additional infected plants. Because ELISA was easier, less expensive, and less time consuming, it was the best method we had for screening for the presence of $X$. fastidiosa in numerous plant samples. Samples testing positive could be confirmed subsequently with PCR.

Strain identification. A list of isolates used in the analysis and sequence accession numbers for each are listed in Table 1. The phylogenetic tree generated is presented in Figure 1. All the strains isolated belong to the same genomic species of $X$. fastidiosa. When bootstrap values higher than $70 \%$ were considered, the phylogenetic tree revealed that field isolates from Temecula Valley fell into three major clusters. Oleander strains isolated from Temecula (H44 and H45) formed a cluster with a previously published OLS strain sequence (Ann1) (18). A second cluster of isolates grouped as PD strains, including isolates from grapevine (A05 and I03), some strains isolated from almond $(189,237$, 239, H10, and H51), and the strain isolated

Table 5. Comparison of enzyme-linked immunosorbent assay (ELISA) and immunocapture polymerase chain reaction (IC/PCR) methods of Xylella fastidiosa detection in field and greenhouse grown plants ${ }^{\mathrm{a}}$

\begin{tabular}{lllcc}
\hline Date, host & Collected & Symptoms & ELISA & IC/PCR \\
\hline May & & & & \\
Grape & Field & Symptomatic & $15 / 25$ & $0 / 25$ \\
Grape & Field & Nonsymptomatic & $0 / 10$ & $0 / 10$ \\
Grape & Greenhouse & Nonsymptomatic & $0 / 10$ & $0 / 10$ \\
Oleander & Greenhouse & Nonsymptomatic & $0 / 2$ & $0 / 2$ \\
Oleander & Greenhouse & Symptomatic & $3 / 3$ & $3 / 3$ \\
June & & & & $7 / 21$ \\
Grape & Field & Symptomatic & $8 / 21$ & $0 / 10$ \\
Grape & Field & Nonsymptomatic & $0 / 10$ & $0 / 8$ \\
Grape & Greenhouse & Nonsymptomatic & $0 / 8$ & $0 / 2$ \\
Oleander & Greenhouse & Nonsymptomatic & $0 / 2$ & $3 / 3$ \\
Oleander & Greenhouse & Symptomatic & $3 / 3$ & \\
\hline
\end{tabular}

${ }^{a}$ Field samples were collected in May and June from grapevines that were symptomatic or nonsymptomatic of infection in the previous year. Greenhouse maintained grapevines and oleanders were used as positive and negative controls. Each sample was divided into two subsamples that were tested with either ELISA or IC/PCR.

Table 4. Detection of Xylella fastidiosa in selected plant species in southern California using enzyme-linked immunosorbent assay

\begin{tabular}{|c|c|c|c|c|c|c|c|c|c|c|c|c|}
\hline \multirow[b]{2}{*}{ Plants } & \multicolumn{12}{|c|}{ Month $^{\mathbf{a}}$} \\
\hline & Jan & Feb & Mar & Apr & May & Jun & Jul & Aug & Sep & Oct & Nov & Dec \\
\hline Grape & + & - & - & - & + & + & + & + & + & + & + & + \\
\hline Almond & + & - & - & - & - & + & + & + & + & + & + & NS \\
\hline Oleander & + & + & + & + & + & + & + & + & + & + & + & + \\
\hline Spanish broom & + & + & + & + & + & + & + & + & + & + & + & + \\
\hline Wild mustard & N/A & N/A & N/A & - & + & + & + & - & - & - & N/A & N/A \\
\hline
\end{tabular}

a Results: $+=$ some plants of this species tested positive during this month; $-=$ plants of this species tested negative during this month; NS = not sampled during that month; N/A = plant species not present in the field. 
from Spanish broom (N10). As expected, isolates from white sage (SAAP110 and SAAP102) and black sage (SAME109) test plants used in the PD strain transmission studies also clustered with the fieldcollected PD strains. The 16S-23S rDNA intergenic regions of strains N10, SAAP110, SAAP102, and SAME109 showed $100 \%$ identity with those previously reported for PD strains (STL and Temecula) $(6,27)$. A third cluster was composed of strains isolated from almond (H50 and 276) that did not group with PD strains. No isolates from Temecula were found to cluster with previously published sequences from citrus, coffee, or pear strains (22). The pear strain was remarkably different from other Xylella strains.

Transmission studies. Studies testing the ability of the GWSS to transmit $X$. fastidiosa from grapevine to 30 species of host plants found transmission of a PD strain of $X$. fastidiosa to grape, black mustard, Spanish broom, almond, black sage, white sage, and Mexican elderberry (Table 2). No transmission of the PD strain to oleander was observed. Previous studies also have demonstrated that transmission of the PD strain to oleander did not occur (18).

\section{DISCUSSION}

The main purpose of this project was to identify potential sources of PD inoculum in the Temecula region. In this survey, relatively few plant species were documented as alternate host plants for PD strains of $X$. fastidiosa in the Temecula Valley. PD strains of $X$. fastidiosa were

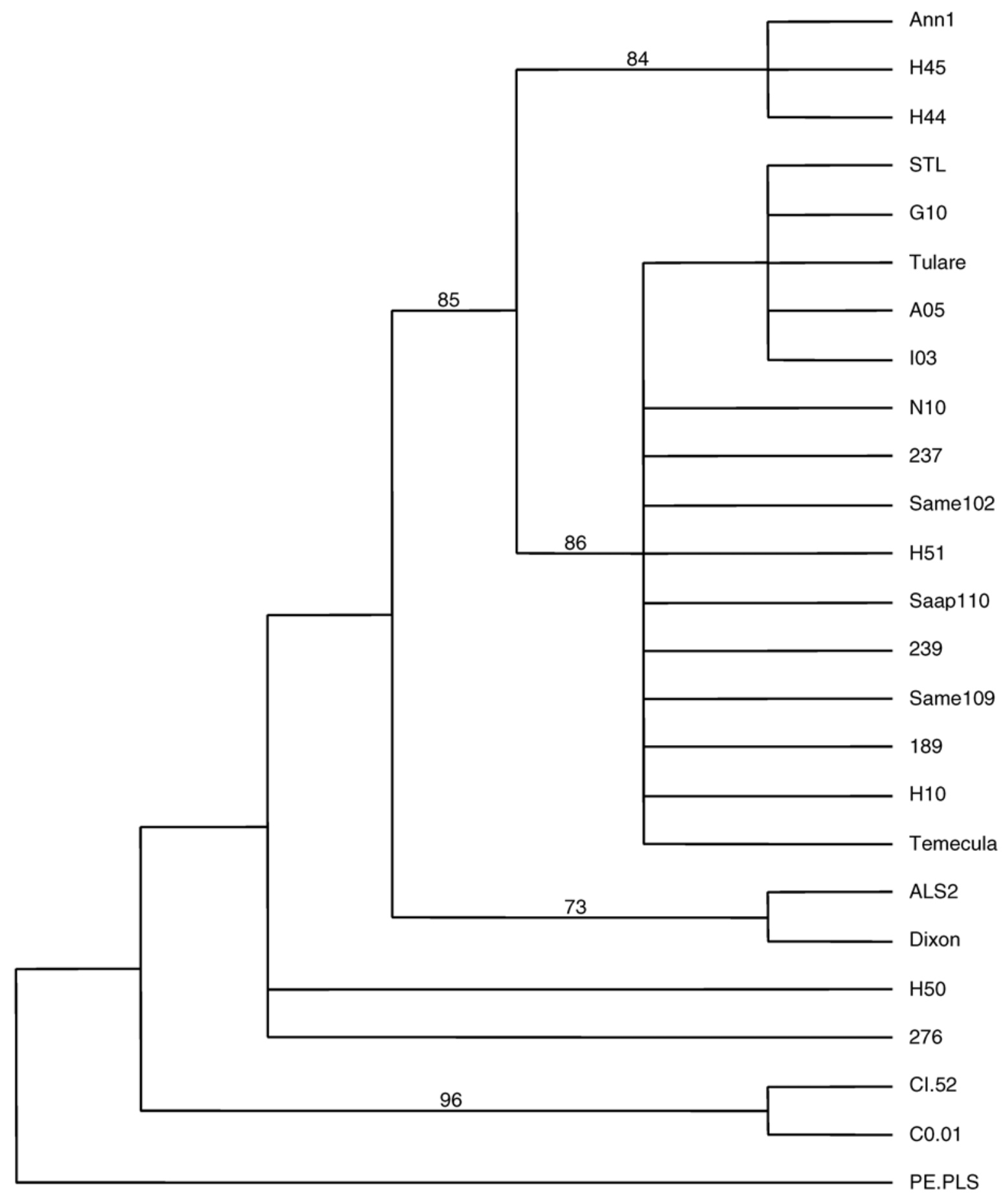

Fig. 1. Phylogenetic tree constructed using the neighbor-joining method, based on 16S-23S rDNA intergenic region sequence data for Xylella fastidiosa with the sequence of the pear strain of $X$. fastidiosa (AF203392) used as the outgroup. The numbers above the branches represent bootstrap values obtained for 100 replications. Identities of strains are listed in Table 1. 
consistently isolated from grapevines, almond trees, Spanish broom, and wild mustard. Isolates from oleander plants were characterized as OLS strains, which are not known to infect grapevine (18), and subsequently should not cause a direct threat to grapevines. The identification of Spanish broom and wild mustard as new hosts of PD strains is important for management of PD because growers previously were unaware that these species could serve as hosts of the pathogen, and they now can remove these weeds from areas surrounding vineyards to reduce outside sources of inoculum. Negative results from sampling of 47 other plant species indicate that, other than grapevines and almond trees, these two weeds were the only alternate hosts of the PD pathogen present in the area. Thus, removal of these species could significantly reduce the impact of alternate hosts on disease incidence. Although negative survey results cannot prove that a plant species can never serve as a host of the pathogen, it does demonstrate that, in this geographic area at this time, these species are not significant sources of inoculum.

Some plants (black sage, white sage, and Mexican elderberry) that became infected with PD strains in our greenhouse transmission studies were never detected as hosts in the field. This could be the result of many factors, including differences in susceptibility of the species or varieties of plants tested, or differences in climatic conditions to which plants were exposed during and after infection. For example, in field studies with caged plants, $X$. fastidiosa could not be detected in several infected plant species after overwintering exposure (17).

Several plant species that were positive for $X$. fastidiosa in field surveys in northern California $(17,19)$ were never confirmed to be positive in samples collected in the Temecula Valley even though they were present near infected vineyards. In addition to the factors mentioned above, this also could be a reflection of differences in the biology and behavior of the insect vector species present in each location, including their feeding preferences and their relative ability to transmit the pathogen to different hosts (21), or a difference in the host ranges of $X$. fastidiosa PD strains present in each location (6).

ELISA tests are very valuable for screening of field samples for bacterial pathogens because they are very sensitive, do not require expensive equipment, and are relatively simple to complete. However, they do have a history of occasional cross-reactions that can result in false positives. In addition, commercially available ELISA kits do not distinguish between strains of $X$. fastidiosa. Because plant host range varies with strain, it is necessary to identify the strain present in positive samples to determine if it is a threat to grape.
Thus, although ELISA continues to be extremely important when screening large numbers of plant samples, additional analysis of positive plant samples with other methods is necessary to eliminate the possibility of false positives with ELISA, and to identify the strains of the pathogen that are present.

Removal of infected plant material is an important management strategy to reduce inoculum sources and decrease the spread of disease. Pathogen detection methods such as ELISA are fairly effective in detecting infected grape petioles beginning in midseason (mid- to late July), when bacterial titers in plants are relatively high; however, they are not as effective in detecting infection earlier in the season (May to June; 19). The use of immunocapture followed by PCR (IC/PCR) theoretically is more effective in detecting purified $X$. fastidiosa cells at lower concentrations than ELISA $(11,12,14)$ and might be expected to be more effective in detecting Xylella-infected grapevines early in the season, when the titer of the pathogen is low. However, in our studies, we found that ELISA was just as effective for detecting the pathogen in leaf tissue samples as the other methods we used (PCR, media culture, and IC/PCR).

Some field samples occasionally tested positive with ELISA (Tables 1 and 3), but the presence of $X$. fastidiosa could not be confirmed with either PCR or culture. This could simply be the result of false positive ELISA reactions. However, failure of PCR $(9,28)$ and culturing $(17)$ techniques due to inhibiting compounds found in certain plant species also can occur. Alternatively, these reactions could be the result of lowlevel or transitory inoculations of $X$. fastidiosa, which never significantly establish in the plants or infect plants at titers too low to be detected by every detection method used. Studies examining the fate of PD strains in alternate hosts in northern California found that most plant hosts of $X$. fastidiosa supported much lower populations of the bacteria than grape and that, in some cases, infection persisted only 1 to 3 weeks after inoculation (17). At this time, it is not known if plants that have transitory or low-level infections in the field can serve as sources of PD inoculum for transmission by GWSS. However, studies by Hill and Purcell (7) using another species of sharpshooter found that there was a threshold population of $X$. fastidiosa in plants, below which vectors could not efficiently acquire the pathogen.

Citrus is a favored host of the GWSS, and is the most important yearlong reproductive host in the Temecula Valley $(8,13)$. Although citrus plants were sampled repeatedly in the field and directly exposed to infected insects in experimental transmission tests, we could never document infection in citrus in the field or in transmission test plants. Citrus collected from the field did occasionally test positive by ELISA; however, the presence of $X$. fastidiosa in citrus samples was never confirmed with PCR or culture and could be false positive ELISA reactions or transient infections, as described above.

Our analysis using sequences of the 16S-23S rRNA spacer region showed two clusters of $X$. fastidiosa isolates from almond in Temecula, some that genetically grouped with the PD strains, and others that did not. Previous characterization of $X$. fastidiosa isolates from almond trees using random amplified polymorphic DNA-PCR analysis also found at least two genetically distinct clusters, some that cause disease in grapevine (PD+) and some that do not (PD-) (2). More detailed testing is being done to characterize the almond and PD isolates of X. fastidiosa present in the host plants identified in the Temecula Valley to determine their relationship to strains found in other geographic areas.

\section{ACKNOWLEDGMENTS}

We thank P. Randhawa and colleagues at California Seed and Plant Laboratory (Elverta, CA) for protocols; H. Azad for assistance with molecular methods; C. Cabrera, J. Cortez, and J. Herras for technical assistance; and numerous cooperators for access to infected plants.

\section{LITERATURE CITED}

1. Almeida, R. P. P., and Purcell, A. H. 2003. Transmission of Xylella fastidiosa to grapevines by Homalodisca coagulata (Hemiptera Cicadellidae). J. Econ. Entomol. 96:264-271.

2. Almeida, R. P. P., and Purcell, A. H. 2003 Homalodisca coagulata (Hemiptera, Cicadellidae) transmission of Xylella fastidiosa to almond. Plant Dis. 87:1255-1259.

3. Blua, M. J., Phillips, P. A., and Redak, R. A. 1999. A new sharpshooter threatens both crops and ornamentals. Calif. Agric. 53:22-25.

4. Davis, M. J., Purcell, A. H., and Thomson, S V. 1980. Isolation media for the Pierce's disease bacterium. Phytopathology 70:425-429.

5. Hartung, J. S., Beretta, J., Brlansky, R. H., Spisso, J., and Lee, R. F. 1994. Citrus variegated chlorosis bacterium: Axenic culture pathogenicity, and serological relationships with other strains of Xylella fastidiosa. Phytopathology 84:591-597.

6. Hendson, M., Purcell, A. H., Chen, D., Smart, C., Guilhabert, M., and Kirkpatrick, B. 2001. Genetic diversity of Pierce's disease strains and other pathotypes of Xylella fastidiosa. Appl. Environ. Microbiol. 67:895-903.

7. Hill, B. L., and Purcell, A. H. 1997. Populations of Xylella fastidiosa in plants required for transmission by an efficient vector. Phytopathology 87:1197-1201.

8. Hix, R., Toscano, N., Redak, R., and Blua, M 2002. Area-wide management of the glassywinged sharpshooter in the Temecula valley. Pages 157-158 in: Proc. Pierce's Dis. Res. Symp. CDFA, Sacramento, CA.

9. Holden, M. J., Blasic, J. R., Jr., Bussjaeger, L., Kao, C., Shokere, L. A., Kendall, D. C., Freese, L., and Jenkins, G. R. 2003. Evaluation of extraction methodologies for corn kernel (Zea mays) DNA for detection of trace amounts of biotechnology-derived DNA. J. Agric. Food Chem. 51:2468-2474.

10. Hopkins, D. L., and Purcell, A. H. 2002. Xylella fastidiosa: Cause of Pierce's disease of grapevine and other emergent diseases. Plant Dis. $86: 1056-1066$. 
11. McElrone, A. J., Sherald, J. L., and Pooler, M. R. 1999. Identification of alternative hosts of Xylella fastidiosa in the Washington, DC area using nested polymerase chain reaction (PCR). J. Arboric. 25:258-263.

12. Minsavage, G. V., Thompson, C. M., Hopkins, D. L., Leite, R. M. V. B. C., and Stall, R. E. 1994. Development of a polymerase chain reaction protocol for detection of Xylella fastidiosa in plant tissue. Phytopathology 84:456461.

13. Perring, T. M., Farrar, C. A., and Blua, M. J. 2001. Proximity to citrus influences Pierce's disease in the Temecula Valley vineyards. Calif. Agric. 55:13-18

14. Pooler, M. R., Hartung, J. S., and Fenton, R. G. 1997. Sequence analysis of a 1296-nucleotide plasmid from Xylella fastidiosa. FEMS Microbiol. Lett. 155:15.

15. Purcell, A. H. 1981. Vector preference and inoculation efficiency as components of resistance to Pierce's disease in European grape cultivars. Phytopathology 71:429-435.

16. Purcell, A. H., and Hopkins, D. L. 1996. Fastidious xylem-limited bacterial plant pathogens. Annu. Rev. Phytopathol. 34:131-151.

17. Purcell, A. H., and Saunders, S. R. 1999. Fate of Pierce's disease strains of Xylella fastidiosa in common riparian plants in California. Plant Dis. 83:825-830.

18. Purcell, A. H., Saunders, S. R., Hendson, M., Grebus, M. E., and Henry, M. J. 1999. Causal role of Xylella fastidiosa in oleander leaf scorch disease. Phytopathology 89:53-58.

19. Raju, B. C., Goheen, A. C., and Frazier, N. W. 1983. Occurrence of Pierce's disease bacteria in plants and vectors in California. Phytopathology 73:1309-1313.

20. Raju, B. C., Nome, S. F., Docampo, D. M., Goheen, A. C., Nyland, G., and Lowe, S. K. 1980. Alternative hosts of Pierce's disease of grapevines that occur adjacent to grape growing areas in California. Am. J Enol. Vitic. 31:144-148.

21. Redak, R. A., Purcell, A. H., Lopes, J. R. S., Blua, M. J., Mizell, R. F., III, and Andersen, P. C. 2004. The biology of xylem fluid-feeding insect vectors of Xylella fastidiosa and their relation to disease epidemiology. Annu. Rev. Entomol. 49:243-270.

22. Rosato, Y. B., Rodrigues Neto, J., Miranda, V. S., Carlos, E. F., and Manfio, G. P. 1998. Diversity of a Xylella fastidiosa population isolated from Citrus sinensis affected by citrus variegated chlorosis in Brazil. Syst. Appl. Microbiol. 21:593-598.

23. Sorensen, J. T., and Gill, R. J. 1996. A range extension of Homalodisca coagulata (Say) (Hemiptera: Clypeorrhyncha: Cicadellidae) to southern California. Pan-Pac. Entomol. 72:160-161.

24. Swofford, D. L. 2002. Phylogenetic Analysis Using Parsimony (and Other Methods). Ver. 4 ed. Sinquer Associates, Sunderland, MA.

25. Thompson, J. D., Gibson, T. J., Plewniak, F., Jeanmougin, F., and Higgins, D. G. 1997. The CLUSTAL-X windows interface: Flexible strategies for multiple sequence alignment aided by quality analysis tools. Nucleic Acids Res. 25:15.

26. Turner, W. F., and Pollard, H. N. 1959. Life histories and behavior of five insect vectors of phony peach disease, U.S. Dep. Agric. Tech. Bull. No. 1188

27. Van Sluys, M. A., de Oliveira, M. C., Monteiro-Vitorello, C. B., Miyaki, C. Y., Furlan, L. R., Camargo, L. E. A., da Silva, A. C. R., Moon, D. H., Takita, M. A., Lemos, E. G. M. Machado, M. A., Ferro, M. I. T., da Silva, F. R., Goldman, M. H. S., Goldman, G. H. Lemos, M. V. F., El-Dorry, H., Tsai, S. M. Carrer, H., Carraro, D. M., de Oliveira, R. C. Nunes, L. R., Siqueira, W. J., Coutinho, L. L., Kimura, E. T., Ferro, E. S., Harakava, R., Kuramae, E. E., Marino, C. L., Giglioti, E. Abreu, I. L., Alves, L. M. C., do Amaral, A. M., Baia, G. S., Blanco, S. R., Brito, M. S Cannavan, F. S., Celestino, A. V., da Cunha, A. F., Fenille, R. C., Ferro, J. A., Formighieri, E. F., Kishi, L. T., Leoni, S. G., Oliveira, A. R. Rosa, V. E., Jr., Sassaki, F. T., Sena, J. A. D. de Souza, A. A., Truffi, D., Tsukumo, F., Yanai, G. M., Zaros, L. G., Civerolo, E. L., Simpson, A. J. G., Almeida, N. F., Setubal, J. C., and Kitajima, J. P. 2003. Comparative analyses of the complete genome sequences of Pierce's disease and citrus variegated chlorosis strains of Xylella fastidiosa. J. Bacteriol. 185:10181026 .

28. Wilson, I. G. 1997. Inhibition and facilitation of nucleic acid amplification. Appl. Environ. Microbiol. 63:3741-3751.

29. Yonce, C. E., and Chang, C. J. 1987. Detection of xylem-limited bacteria from sharpshooter leafhoppers and their feeding hosts in peach environs monitored by culture isolations and ELISA techniques. Environ. Entomol. 16:68-71. 